\title{
Zoledronate upregulates MMP-9 and -13 in rat vascular smooth muscle cells by inducing oxidative stress
}

\author{
This article was published in the following Dove Press journal: \\ Drug Design, Development and Therapy \\ I8 April 2016 \\ Number of times this article has been viewed
}

\author{
Mehmet Zuhuri Arun' \\ Buket Reel' \\ Graciela B Sala-Newby ${ }^{2}$ \\ Mark Bond ${ }^{2}$ \\ Aikaterini Tsaousi \\ Perry Maskell² \\ Andrew C Newby ${ }^{2}$ \\ 'Department of Pharmacology, Faculty \\ of Pharmacy, Ege University, Izmir, \\ Turkey; ${ }^{2}$ Bristol Heart Institute, \\ University of Bristol, Bristol Royal \\ Infirmary, Bristol, UK
}

Background: Bisphosphonates, including zoledronate, target osteoclasts and are widely used in the treatment of osteoporosis and other bone resorption diseases, despite side effects that include damaging the stomach epithelium. Beneficial and adverse effects on other organ systems, including the cardiovascular system, have also been described and could impact on the use of bisphosphonates as therapeutic agents. Vascular smooth muscle cells (VSMCs) are major constituents of the normal vascular wall and have a key role in intimal thickening and atherosclerosis, in part by secreting MMPs that remodel the extracellular matrix and cleave cell surface proteins or secreted mediators. In this study, we investigated the effects of zoledronate on MMP expression.

Methods: Rat VSMCs were stimulated by PDGF (50 ng/mL) plus TNF- $\alpha(10 \mathrm{ng} / \mathrm{mL})$ or left unstimulated for a further 24 hours in serum-free medium. In other series of experiments, cells were pre-treated either with SC-514 $(50 \mu \mathrm{M})$ or with apocynin $(20 \mathrm{nM})$ for 2 hours, then zoledronate $(100 \mu \mathrm{M})$ was added into $2 \%$ fetal calf serum containing medium for 24 hours.

Results and discussion: Using isolated rat VSMCs in culture, zoledronate $(100 \mu \mathrm{M})$ increased MMP-9 and -13 mRNA expressions but inhibited MMP-2 expression. MMP-9 and MMP-13 up-regulation was shown to depend on the NF- $\mathrm{KB}$ pathway; and this was activated by zoledronate. Furthermore, zoledronate elevated the levels of reactive oxygen species detected by either dichlorofluorescein in isolated VSMCs or lucigenin enhanced chemiluminescence in rat aortic rings in vitro. Apocynin, an inhibitor of NADPH oxidase, reversed NF- $\kappa B$ activation and MMP-9 and MMP-13 up-regulation by zoledronate.

Conclusion: We conclude that zoledronate increases MMP-9 and MMP-13 expressions in rat VSMCs dependent upon stimulation of the NF- $\mathrm{KB}$ pathway by reactive oxygen species. Effects on MMP expression may contribute to the pharmacologic profile of bisphosphonates.

Keywords: vascular smooth muscle cell, matrix metalloproteinase, bisphosphonate, reactive oxygen species, zoledronate

\section{Introduction}

Bisphosphonates are widely used clinically for the treatment of osteoporosis and bone metastasis. Although they primarily target osteoclasts, adverse and beneficial effects on other organ systems have been described. Destruction of the gastric epithelium by high concentrations of bisphosphonates is a recognized off-target effect. On the contrary, beneficial effects on atherosclerosis have also been described, ${ }^{1-3}$ although the precise mechanisms involved have not been elucidated.

Migration and proliferation of vascular smooth muscle cells (VSMCs) play key roles in the development of vascular proliferative diseases such as atherosclerosis and restenosis. ${ }^{4}$ Moreover, previous studies showed that bisphosphonates inhibit adhesion of
Correspondence: Mehmet Zuhuri Arun Department of Pharmacology, Faculty of Pharmacy, Ege University, 35100 Bornova, Izmir, Turkey Tel +902323113288

Fax +902323884687

Email mehmet.arun@ege.edu.tr
Drug Design, Development and Therapy 2016:10 1453-1460

(c) (1) (8) ๑ 2016 Arun et al. This work is published and licensed by Dove Medical Press Limited. The full terms of this license are available at https//www.dovepress.com/terms.php cc) hereby accept the Terms. Non-commercial uses of the work are permitted without any further permission from Dove Medical Press Limited, provided the work is properly attributed. For permision for commercial use of this work, please see paragraphs 4.2 and 5 of our Terms (https://www.doveppess. com/terms.php).
Dovepress

http://dx.doi.org/10.2147/DDDT.S103124 
VSMCs to extracellular matrix components in tissue culture, as well as their proliferation and migration., ${ }^{5,6}$ The end result is decreased neointimal hyperplasia both in preclinical and clinical investigations. ${ }^{7-9}$ MMPs play a variety of roles in normal vascular physiology and pathology. For example, increased expression of MMP-13 (especially in rodents) can degrade fibrillar type I and III collagen, thereby increasing atherosclerotic plaque's vulnerability to rupture. ${ }^{10}$ Conversely, MMP-2 and MMP-9 stimulate migration and proliferation of VSMCs by degrading basement components including type IV collagen. This contributes to restenosis but may prevent plaque rupture thanks to formation of a more stable plaque cap. ${ }^{11}$

Bisphosphonates have been reported to inhibit expression and activity of some MMPs in different steps of cancer progression. ${ }^{12-14}$ However, the effects of bisphosphonates on MMPs implicated in the pathogenesis of atherosclerosis and restenosis have not been elucidated. In this study, we therefore investigated the effects of zoledronate, which is a highly potent bisphosphonate, on MMP-2, MMP-9, and MMP-13 expressions in rat VSMCs.

\section{Materials and methods Cell culture}

\section{Primary rat cells}

Male Sprague Dawley rats were killed by cervical dislocation in accordance with the Directive 2010/63/EU of the European Parliament. Approval was granted by the University of Bristol ethical review board. VSMCs (four separate preparations from different rats) were obtained by the explant method from thoracic aortas and were cultured in Dulbecco's Modified Eagle's Medium (Lonza, Basel, Switzerland) containing 10\% fetal calf serum (FCS), penicillin (100 mg/mL), streptomycin (100 U/ $\mathrm{mL})$, and L-glutamine ( $2 \mathrm{mM})$. VSMCs were used between passage 6 and 8 in the experiments, which is within the limits (passage $3-8$ ) of previous studies. ${ }^{15}$ Reduced serum (2\%) or serum-free conditions were used in some incubations to avoid interfering with the zymographic assays, and were well tolerated by VSMCs. ${ }^{16}$

\section{Treatment of the cells}

Zoledronate (Novartis International AG, Basel, Switzerland) was obtained as a $2.94 \mathrm{mM}$ sterile, neutral aqueous solution for intravenous infusion containing $4 \mathrm{mg}$ of zoledronate, $220 \mathrm{mg}$ mannitol, and $24 \mathrm{mg}$ sodium citrate in $5 \mathrm{~mL}$. Cells were seeded into 12-well plates. When they became confluent, they were pre-treated with zoledronate to a final concentration of $100 \mu \mathrm{M}$ zoledronate or kept as untreated in $2 \%$ FCS containing medium for 24 hours. Given the high dilution and innocuous nature of the vehicle, untreated cells were used as a control. Cells were stimulated by PDGF $(50 \mathrm{ng} / \mathrm{mL})$ plus TNF- $\alpha$ (10 ng/mL) or left unstimulated for a further 24 hours in serum-free medium. In other series of experiments, cells were pre-treated either with SC-514 (Cayman Chemicals MA, USA), $(50 \mu \mathrm{M})^{17}$ or with apocynin $(20 \mathrm{nM})$ for 2 hours, then zoledronate $(100 \mu \mathrm{M})$ was added into $2 \%$ FCS containing medium for 24 hours.

\section{Real-time polymerase chain reaction (PCR) analysis}

Total RNA were extracted from VSMCs using the total RNA extraction kit (Ambion, Thermo Fisher Scientific, Waltham, MA, USA), according to the manufacturer's instructions. Extracted RNA was quantified using Nanodrop ${ }^{\mathrm{TM}} 1000$ Spectrophotometer (Thermo Fisher Scientific) and reverse transcribed using a Roche Reverse Transcription Kit (Hoffman-La Roche Ltd., Basel, Switzerland) (100 ng RNA per reaction). A genomic DNA removal step was included, and the resulting cDNA was diluted in $10 \mathrm{mM}$ Tris- $\mathrm{HCl}$, $\mathrm{pH}$ 8. Real-time quantitative PCR was performed in Illumina Eco Real-Time PCR with Roche SYBR Green Master Mix and primers for MMP-2, MMP-9, MMP-13, IאB, and 36B4, which is a housekeeping gene. Primers are listed in Table 1.

Table I Primer sequences used for real-time polymerase chain reaction

\begin{tabular}{|c|c|c|}
\hline Gene symbol & Accession number & Primer sequences \\
\hline \multirow[t]{2}{*}{ MMP-2 } & NM_031054 & F: GGGAGCGCAAGGATGGAGGCACGA \\
\hline & & R: CCAGCAGGCAGCACAGGACGCAGA \\
\hline \multirow[t]{2}{*}{ MMP-9 } & NM_031055 & F: AGGCGCCGTGGTCCCCACTTACTT \\
\hline & & R: GCAGGGTTTGCCGTCTCCGTTGCC \\
\hline \multirow[t]{2}{*}{$M M P-13$} & NM_133530 & F: TCGCATTGTGAGAGTCATGCCAACA \\
\hline & & R: TGTGGTTCCAGCCACGCATAGTCA \\
\hline \multirow[t]{2}{*}{$I \kappa B$} & NM_00II05720 & F: CTACTGGACGACCGCCACGACAGC \\
\hline & & R:CGAGGCGGATCTCCTGCAGCTCCTTG \\
\hline $36 B 4$ & NM 022402 & F: GCCAGCGAAGCCACGCTGCTGAAC \\
\hline
\end{tabular}

Note: National Center for Biotechnology Information accession number, gene symbol, and sequences of forward (F) and reverse (R) primers. 
To confirm amplification specificity, PCR products from each primer pair were subjected to agarose gel electrophoresis. Relative mRNA expression levels were calculated by using the Delta-Delta $\mathrm{Ct}$ method using 36B4 as a normalization control.

\section{Western blotting and gelatin zymography}

Conditioned media of the cells were collected and concentrated using centrifugal filter units (Merck Millipore, Billerica, MA, USA). Cells were lysed in sodium dodecyl sulfate (SDS) buffer (2\% SDS [w/v], 16\% glycerol [v/v], and $50 \mathrm{mM}$ Tris [pH 6.8]). Protein concentration in lysates was measured using BCA Protein Assay Kit (Thermo Fisher Scientific) and was used to normalize loading of gels.

MMP-9 activity in conditioned medium was determined by gelatin zymography as described previously. ${ }^{17}$ Briefly, $7.5 \%$ polyacrylamide gels containing $2 \mathrm{mg} / \mathrm{mL}$ of gelatin were subjected to electrophoresis. Following electrophoresis, SDS was removed by washing in $2.5 \%$ Triton X-100. Gels then were incubated at $37^{\circ} \mathrm{C}$ for 48 hours in incubation buffer $(50$ mM Tris-HCl, pH 8.0, $50 \mathrm{mM} \mathrm{NaCl}, 10 \mathrm{mM} \mathrm{CaCl}_{2}$, and $0.05 \%$ Triton X-100). Ethylenediaminetetraacetic acid (EDTA) inhibits MMP activity by chelating $\mathrm{Zn}^{2+}$ on enzymes' catalytic domain. In order to verify if the detected bands were MMP-2 and -9 , another gel was incubated in calcium-free incubation solution containing $10 \mathrm{mM}$ EDTA. After the incubation period, gels were stained in $0.2 \%$ Coomassie Brilliant Blue. Images of the gels were captured with a scanner. Gelatinase activity was detected as clear bands on dark backgrounds.

For Western blotting, equal total protein concentrations (see above) were loaded on $8 \%-10 \%$ polyacrylamide gels and transferred onto polyvinylidene difluoride membranes as described previously. ${ }^{18}$ These were blocked for an hour in 5\% $(\mathrm{w} / \mathrm{v})$ skimmed milk powder and incubated overnight at $4^{\circ} \mathrm{C}$ with anti-MMP-13 (catalog no ab39012; Abcam, Cambridge, UK) (1:2,000 in 5\% BSA:Tris-buffered saline). Bound primary antibodies were detected by horseradish peroxidaseconjugated antibodies (Sigma-Aldrich Co., St Louis, MO, USA; catalog no A6154) (1:5,000 in 5\% BSA:Tris-buffered saline) and enhanced chemiluminescence (Amersham International, Buckinghamshire, UK).

\section{Detection of reactive oxygen species (ROS) in rat thoracic aortic rings}

This study was approved by the Local Ethics Committee of Dokuz Eylul University School of Medicine. All animals received care in compliance with the principles of laboratory animal care formulated by the National Society for Medical Research and with the Guide for the Care and Use of Laboratory Animals prepared by the Institute of Laboratory Animal Resources.

Levels of superoxide anion and other ROS in aortic rings were measured as previously described. ${ }^{19}$ In this study, Wistar rats were euthanized by decapitation under ketamine/xylazine anesthesia. The thoracic aorta segment was dissected. Following careful removal of loose connective tissue, thoracic aorta was cut into $2 \mathrm{~mm}$ rings. The rings were then transferred into Dulbecco's Modified Eagle's Medium/F12 (Gibco, Thermo Fisher Scientific) cell culture medium containing 2\% FCS immediately. The rings were incubated in cell culture medium in the presence or absence of $100 \mu \mathrm{M}$ zoledronate for 24 hours in a humidified atmosphere containing 5\% $\mathrm{CO}_{2}$ at $37^{\circ} \mathrm{C}$. Subsequently, aortic rings were transferred to solid white well plates containing $200 \mathrm{~mL}$ of HEPESbuffered Krebs-Henseleit solution ( $\mathrm{pH}$ 7.4). After addition of chemiluminescence enhancers, lucigenin or luminol (final concentration of $5 \mu \mathrm{mol} / \mathrm{L}$ for either), ROS were quantified using a multi-plate reader (Victor III-1420; PerkinElmer Inc., Waltham, MA, USA). Counts were obtained every 10 seconds and normalized per mg of wet tissue weight. Results were expressed as the area under curve for a counting period of 5 minutes of relative light units (rlu)/wet tissue (mg).

\section{Statistical analysis}

Statistical analyses were performed using the Prism software v.4 (GraphPad Software, Inc., La Jolla, CA, USA). Multiple comparisons were subjected to one-way analysis of variance followed by post hoc Bonferroni correction. Paired Student's $t$-tests were performed to compare means of lucigenin/ luminol measurements. When necessary, data were normalized by $\log$ transformation. Normalized data were expressed as mean \pm standard error of the mean $P \leq 0.05$ was considered statistically significant.

\section{Results}

\section{Effects of zoledronate on expression of MMPs with and without induction by PDGF and TNF- $\alpha$}

Because of their diverse roles and regulation patterns, we studied constitutively expressed gelatinase, MMP-2, together with another gelatinase, MMP-9, and a collagenase, MMP-13, that could be induced by a combination of PDGF and TNF- $\alpha$.

\section{Gelatinase A/MMP-2}

MMP-2 was constitutively expressed in VSMCs (Figure 1A, B), in agreement with previous studies. ${ }^{16}$ Zoledronate pre-treatment did not change constitutive MMP-2 mRNA levels 

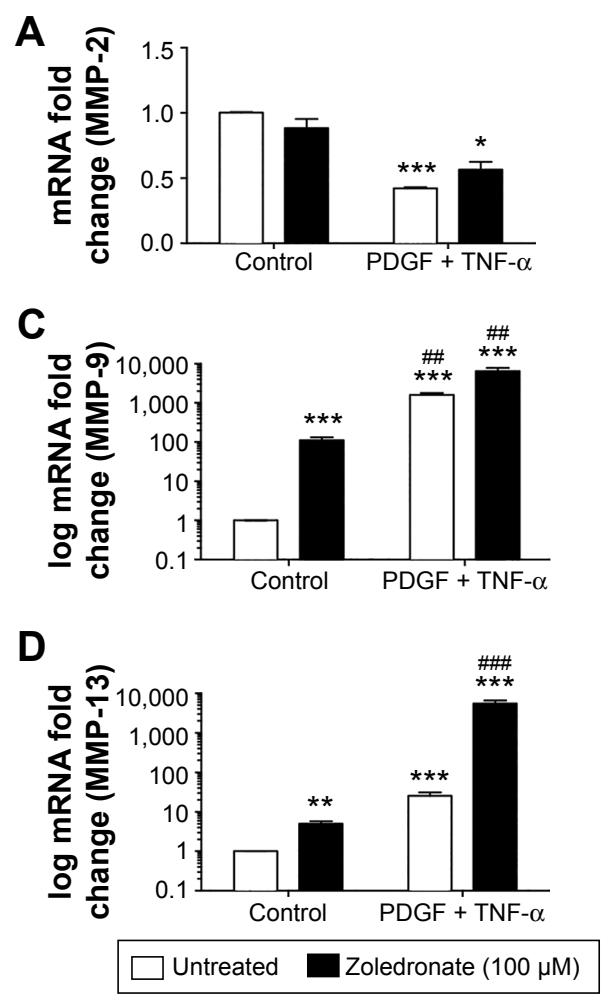

B
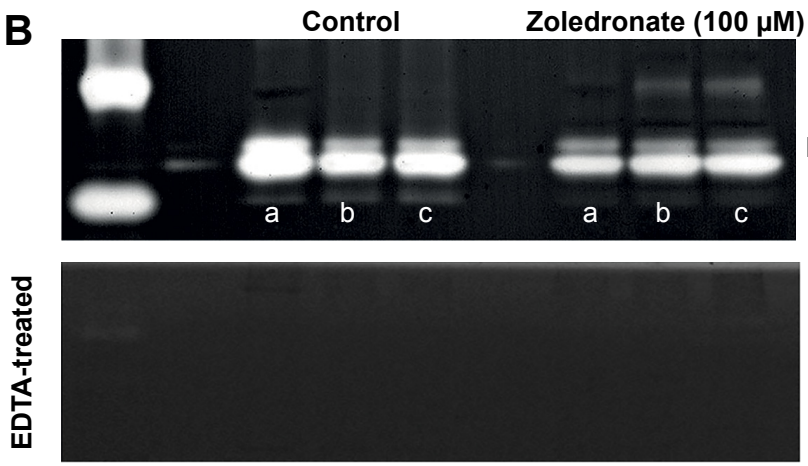

E

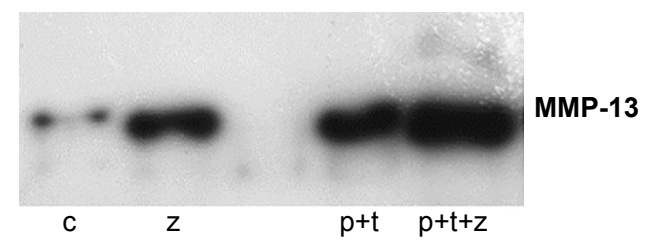
MMP-9 MMP-2

Figure I Effects of PDGF plus TNF- $\alpha$ and zoledronate (48 hours) on MMP-2, -9 , and -13 .

Notes: (A) MMP-2 mRNA expression. *** $\mathrm{P} \leq 0.00 \mathrm{I}, * \mathrm{P} \leq 0.05$ vs Control-Untreated, $\mathrm{n}=3$. (B) MMP-2 and MMP-9 protein expressions. A representative zymogram a: No induction; b: PDGF $(50 \mathrm{ng} / \mathrm{mL})+$ TNF- $\alpha$-induced $(10 \mathrm{ng} / \mathrm{mL})$; c: PDGF $(50 \mathrm{ng} / \mathrm{mL})+$ TNF- $\alpha$-induced $(50 \mathrm{ng} / \mathrm{mL})$. (C) MMP-9 mRNA expression. $* * P \leq 0.0 \mathrm{I}$, $* * * P \leq 0.00 \mathrm{I}$ vs Control-untreated, ${ }^{\# P} \leq 0.01$ vs control-zoledronate $(n=3)$. (D) MMP-I3 mRNA expression $* * P \leq 0.01$, $* * * P \leq 0.001$ vs control untreated, ${ }^{*} P \leq 0.01$ vs control-zoledronate $(\mathrm{n}=3)$. (E) Protein expression of MMP-13 by Western blotting. Lanes No induction (c); Zoledronate $(100 \mu M)(z)$; PDGF $(50 \mathrm{ng} / \mathrm{mL})+\mathrm{TNF}-\alpha-i n d u c e d(50 \mathrm{ng} / \mathrm{mL})(\mathrm{p}+\mathrm{t})$; PDGF + TNF- $\alpha+$ Zoledronate $(p+t+z)$.

Abbreviation: EDTA, ethylenediaminetetraacetic acid.

(Figure 1A). PDGF plus TNF- $\alpha$ treatment significantly decreased MMP-2 mRNA levels to a similar extent in untreated and zoledronate pre-treated cells (Figure 1A). This was confirmed by zymography in which MMP-2 appeared as a major $72 \mathrm{kDa}$ band (Figure 1B) that disappeared on incubation in the presence of EDTA (lower panel).

\section{Gelatinase B/MMP-9}

MMP-9 was expressed at barely detectable levels in quiescent VSMCs (Figure 1B, C) also in agreement with previous work. ${ }^{16}$ However, zoledronate pre-treatment significantly increased MMP-9 mRNA levels (Figure 1C). PDGF plus TNF- $\alpha$ induced even higher MMP-9 mRNA levels and this effect was enhanced by zoledronate pre-treatment (Figure 1C). Consistent with this, only after PDGF plus TNF- $\alpha$ induction of zoledronate pre-treated cells was MMP-9 protein detectable by zymography as a $92 \mathrm{kDa}$ band (Figure 1B) that disappeared on incubation in the presence of EDTA (lower panel).

\section{Collagenase 3/ MMP-I3}

The effects of zoledronate on MMP-13 expression were similar to those on MMP-9. Zoledronate pre-treatment significantly increased MMP-13 mRNA and protein levels in control cells (Figure 1D, E). PDGF plus TNF- $\alpha$ induction increased MMP-13 mRNA and protein levels even further, and these were additively increased in zoledronate treated cells (Figure 1D, E).

\section{Role of NF- $\kappa B$ in MMP-9 and MMP-I 3 induction}

The NF- $\kappa$ B pathway was previously shown to play an essential role in up-regulation of MMP-1, MMP-3, and MMP-9 in rabbit and human VSMCs using gene transfer of a dominant negative form of the inhibitor of $\kappa \mathrm{B}, \mathrm{I} \kappa \mathrm{B} \alpha{ }^{16}$ We also showed ${ }^{17}$ that induction of several MMPs in human monocytes can be reversed by using SC-514, which is a selective inhibitor of I $\kappa$ B kinase $2 .{ }^{20}$ We therefore used SC-514 to investigate whether NF- $\mathrm{BB}$ also mediates MMP-9 and MMP-13 up-regulation in rat VSMCs. SC-514 had no effect on the barely detectable levels of MMP-9 (Figure 2A) or MMP-13 (Figure 2B) mRNA in dimethyl sulfoxide treated cells. However, SC-514 strongly inhibited induction of MMP-9 and MMP-13 by PDGF plus TNF- $\alpha$, thereby demonstrating the importance of NF- $\mathrm{KB}$ in up-regulation of both these MMPs. To investigate whether zoledronate activated 
A

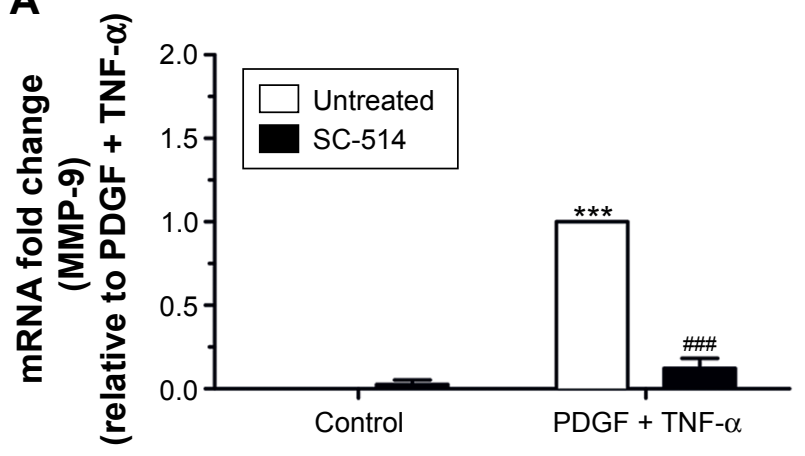

B

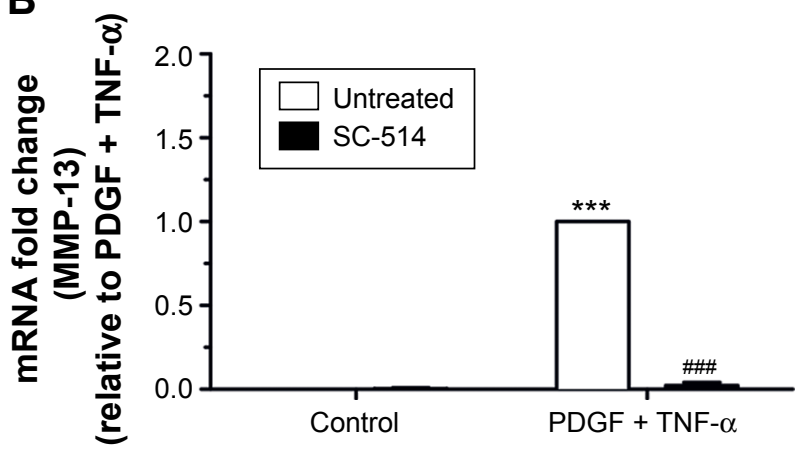

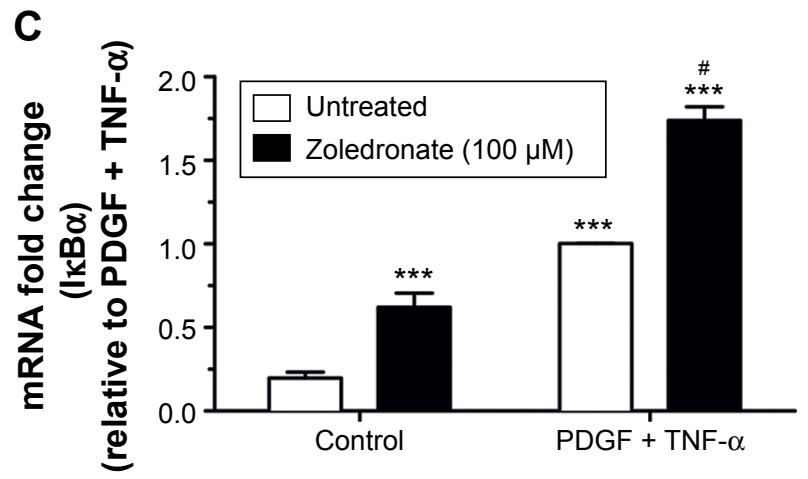

Figure 2 Evidence for involvement of the NF- $\kappa B$ pathway.

Notes: (A) Effects of IKB kinase 2 inhibitor SC-5I $4(50 \mu \mathrm{M})$ were measured on MMP-9 mRNA expression. $* * * P \leq 0.00$ I untreated vs PDGF plus TNF- $\alpha$ induction, ${ }^{\ldots} P \leq 0.00$ I

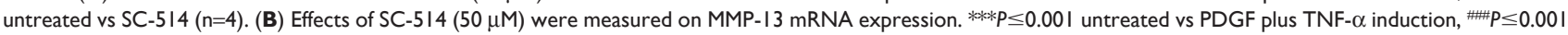
untreated vs SC-5I4 ( $n=4)$. (C) Effects of PDGF plus TNF- $\alpha$ induction and zoledronate treatment (48 hours) were measured on IKB $\alpha$ mRNA expression levels. $* * * P \leq 0.0$ I vs control - untreated, ${ }^{P} \leq 0.05$ untreated vs $S C-5 \mid 4(n=3)$.

the NF- $\kappa \mathrm{B}$ pathway in VSMCs, we measured expression of $\mathrm{I} \kappa \mathrm{B} \alpha \mathrm{mRNA}$ because its promoter is a direct target of $\mathrm{NF}-\kappa \mathrm{B}$ activation in a process designed to cause feedback inhibition. ${ }^{21}$ Detectable levels of I $\kappa \mathrm{B} \alpha$ mRNA were present in quiescent VSMCs (Figure 2C) but, similarly to MMP-9 and MMP-13, these were significantly augmented by pretreatment with zoledronate (Figure 2C). PDGF plus TNF- $\alpha$ increased $\mathrm{I} \kappa \mathrm{B} \alpha \mathrm{mRNA}$ levels even further and this was also enhanced by zoledronate pre-treatment (Figure 2C).

\section{ROS production in zoledronate treated isolated VSMCs and aortas}

The NF- $\kappa B$ pathway is known to be sensitive to ROS production in VSMCs, independently of the effects of inflammatory mediators. ${ }^{22} \mathrm{We}$ therefore investigated whether ROS production in response to zoledronate might be responsible for activation of the NF- $\kappa$ B pathway, and hence MMP-9 and MMP-13 induction. Firstly, to confirm the activation of ROS, a dichlorofluorescein assay was performed to quantify cellular oxidative stress in isolated rat VSMCs. The cells were treated with zoledronate or PDGF plus TNF- $\alpha$, with untreated cells as control. The results showed clearly that zoledronate treatment increased ROS levels, whereas no significant effect was observed with PDGF plus TNF- $\alpha$ (Figure 3A).
For further confirmation, ROS levels were measured by using lucigenin or luminol in intact rat aortic tissue studied ex vivo. Incubation of rat aortic rings with zoledronate $(100 \mu \mathrm{M})$ for 24 hours significantly elevated lucigenin enhanced chemiluminescence by approximately 2.5 times compared to control, untreated aortic rings (Figure 3B). The data for luminol enhanced chemiluminescence showed the same trend but was not significant ( $P=0.116$, Figure $3 \mathrm{~B})$.

\section{Effects of NADPH oxidase inhibitor, apocynin, on induction of MMP-9, MMP-I3, and $I \kappa B$ mRNAs}

NADPH oxidase is a prominent source of ROS in VSMCs. ${ }^{23}$ We therefore investigated the effects of apocynin, which is an inhibitor of NADPH oxidase. Apocynin reversed the elevation of MMP-9 mRNA levels in zoledronate pre-treated cells but had no significant effect on untreated cells (Figure 4A). Apocynin significantly decreased MMP-13 mRNA levels in untreated cells, and also normalized the high levels of MMP-13 mRNA expression in zoledronate pre-treated cells (Figure 4B). Furthermore, apocynin significantly inhibited NF- $\mathrm{BB}$ activation measured by the increase in mRNA levels of I $\kappa B-\alpha$ in zoledronate pre-treated cells, but had no effect on untreated cells (Figure 4C). 

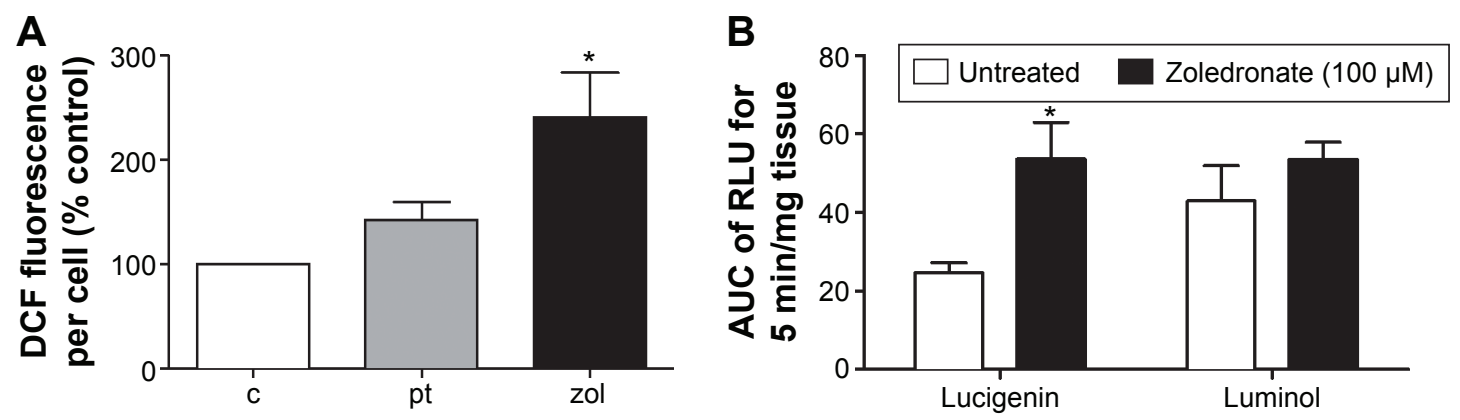

Figure 3 Effects of zoledronate on ROS levels in rat VSMCs and aortic rings.

Notes: (A) ROS levels determined by dichlorofluorescein (DCF) fluorescence were compared in control (c), PDGF (50 ng/mL) plus TNF- $\alpha$ (I0 $\mathrm{ng} / \mathrm{mL})$ induced (pt) and zoledronate pre-treated (zol, $100 \mu \mathrm{M})$ cells. $* P \leq 0.05$ control vs zoledronate $(n=4)$. (B) Lucigenin or luminol enhanced chemiluminescence was measured in control and $100 \mu \mathrm{M}$ zoledronate pre-treated isolated rat aortic rings. $* P \leq 0.05$ control vs zoledronate, paired Student's $t$-test, $(n=5)$.

Abbreviations: ROS, reactive oxygen species; VSMCs, vascular smooth muscle cells; AUC, area under curve; RLU, relative light units.

\section{Discussion}

In this study, we investigated the effects of zoledronate in primary rat VSMCs on expression of three abundant MMPs that are known to influence their migration, proliferation, and apoptosis. We chose MMP-2, MMP-9, and MMP-13 since they show diverse substrate specificity and response to induction by PDGF plus TNF- $\alpha$. Our data, for the first time, demonstrated that zoledronate induced expression of MMP-9 and MMP-13 but not MMP-2. Then, we investigated the possible underlying mechanisms and revealed that zoledronate may have a role in ROS production and activation of the NF- $\kappa B$ pathway.
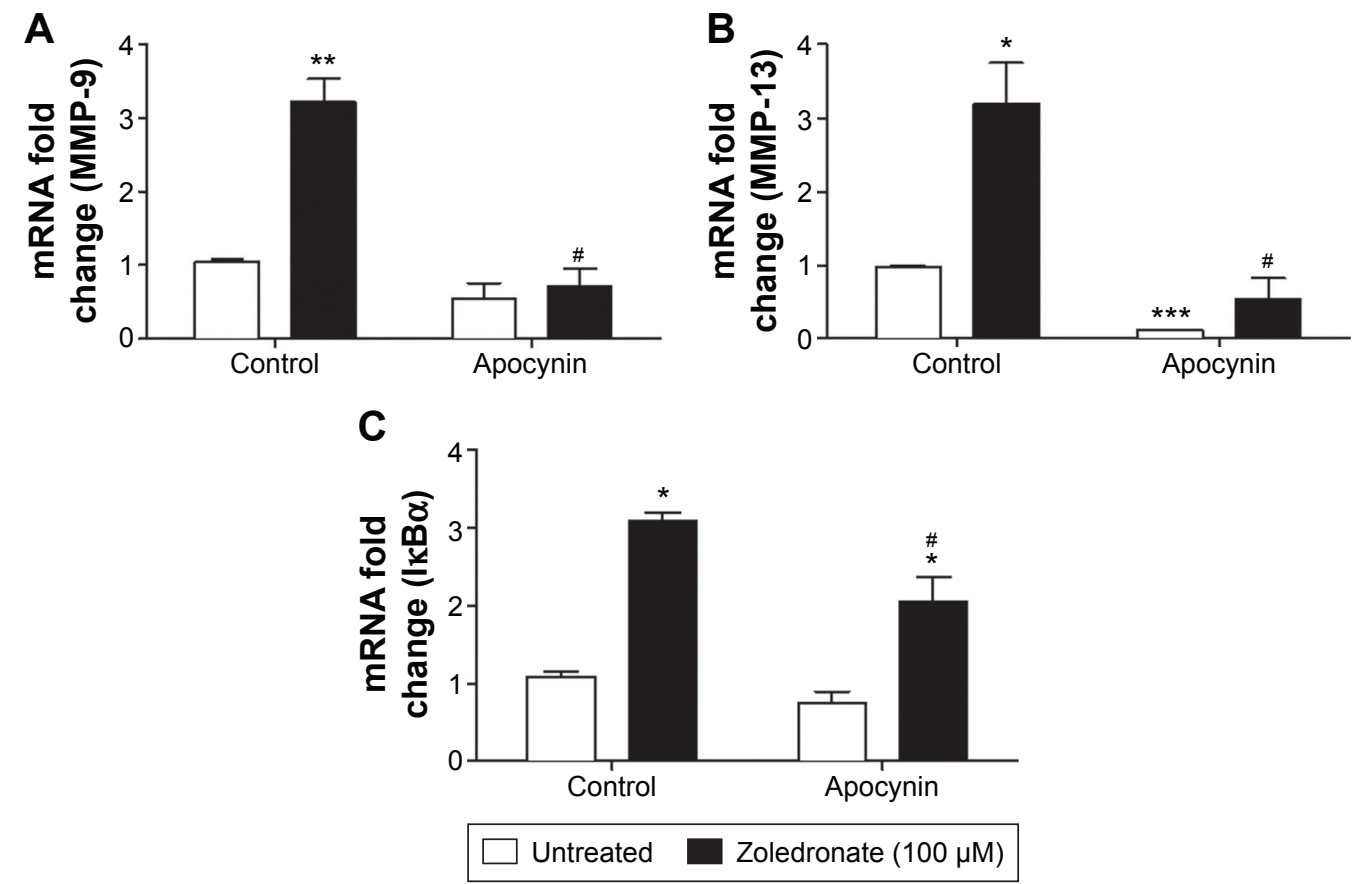

Figure 4 Effects of apocynin with and without zoledronate on MMP-9, - I3, and IKB $\alpha$.

Notes: (A) MMP-9 mRNA expression. **P $\leq 0.01$, ${ }^{*} P \leq 0.05$ vs control - zoledronate. (B) MMP-I 3 mRNA expression. $* P \leq 0.05$, *** $P \leq 0.01$ vs control - untreated, ${ }^{*} P \leq 0.05$ vs control - zoledronate. (C) I $\mathrm{B} \alpha \alpha$ mRNA expression. $* P \leq 0.05$ vs control - untreated; ${ }^{*} P \leq 0.05$ control vs apocynin $(n=4)$. 
bisphosphonate similar to zoledronate, at concentrations of $30 \mu \mathrm{M}$ to $300 \mu \mathrm{M}$, caused a 5- to 10 -fold increase in MMP-9 mRNA levels in human monocytes. ${ }^{25}$ Nitrogen containing bisphosphonate, alendronate markedly stimulated mRNA levels of MMP-13 in primary rat osteoblasts at concentrations higher than $10 \mu \mathrm{M} .{ }^{26}$ While these results support our basic findings, none of the published studies identified the underlying mechanisms.

We showed here that NF- $\kappa B$ activity is essential for up-regulation of MMP-9 and MMP-13 in rat VSMCs using the competitive inhibitor of $\kappa \mathrm{B}$ kinase 2 , SC-514. ${ }^{20} \mathrm{SC}-514$ can target other unrelated kinases PIM3, PIM1, DYRK1A, DYRK3, and Aurora B with similar affinity. ${ }^{27}$ However, MMP-1, MMP-3, and MMP-9 transcription in rabbit and human VSMCs ${ }^{16}$ was also inhibited by adenovirus-mediated gene transfer of dominant negative $\mathrm{I} \kappa \mathrm{B} \alpha$, which reinforces the specific role of NF- $\kappa$ B in MMP-9 induction. Similarly, $\mathrm{NF}-\kappa \mathrm{B}$ activation was shown to be essential for MMP-13 induction in chondrocytes. ${ }^{28}$

We hypothesized, furthermore, that zoledronate can activate the NF- $\mathrm{BB}$ pathway. We found from preliminary experiments, that the effects of zoledronate required a 24-hour pre-incubation (results not shown). This implied that any activation of NF- $\kappa \mathrm{B}$ would be slow and the method to detect it would need to be sensitive to prolonged activation. Acute activation is triggered by phosphorylation of I $\mathrm{B} \alpha$ which is then targeted for degradation by the $26 \mathrm{~S}$ proteasome, allowing NF- $\kappa \mathrm{B}$ dimers to translocate to the nucleus, usually within minutes, and activate transcription. ${ }^{21}$ Subsequently, one of the primary targets for active NF- $\kappa \mathrm{B}$ is the I $\mathrm{B} \alpha$ gene, which drives re-synthesis of the I $\mathrm{B} \mathrm{B} \alpha$ protein and feeds back on the activation cascade. ${ }^{21}$ As a consequence, I $\mathrm{B} \alpha \alpha \mathrm{mRNA}$ accumulates over an extended time period and we argued that this might provide a suitable measurement to investigate the effects of zoledronate. In fact, we found clear evidence that zoledronate pre-treatment increased $\mathrm{I} \kappa \mathrm{B} \alpha \mathrm{mRNA}$ and therefore slowly induced NF- $\kappa \mathrm{B}$ activation. However, the findings from this study regarding $N F-\kappa B$ require further investigation, since the current study did not examine the protein expressions of NF- $\mathrm{kB}$.

To answer the question regarding how zoledronate activated NF- $\mathrm{BB}$, we set up additional experiment series in rat VSMCs. Our results from dichlorofluorescein experiments showed that zoledronate treatment increased ROS levels; and this finding was confirmed with an experiment on rat thoracic aortic rings by lucigenin measurements. Our evidences are consistent with previous experiments demonstrating bisphosphonate induced superoxide production in gastric and small intestinal epithelial cells. ${ }^{29}$ In addition, zoledronate administration $(100 \mu \mathrm{g} / \mathrm{kg}$ subcutaneously for 28 days) caused increased oxidative stress and decreased antioxidant levels in rabbit livers. ${ }^{30}$ To confirm the role of oxidative stress in NF- $\mathrm{KB}$ activation and up-regulation of MMP-9 and MMP-13, we showed that apocynin, an inhibitor of NADPH oxidase, significantly inhibited these effects of zoledronate in VSMCs.

Our results provide new understanding regarding the pharmacological effects of bisphosphonates in the cardiovascular system. They are of particular relevance to pathologies, such as restenosis and vein graft intimal thickening, where there is a predominant role of VSMCs. ${ }^{4}$ Other sources of MMPs, such as macrophages, become relevant in the context of atherosclerosis, ${ }^{4}$ and it would be interesting, in future studies, to investigate how they respond to zoledronate treatment. Moreover, the NF- $\kappa \mathrm{B}$ pathway has an established role in the induction of several MMPs in diverse cell types including: human epithelial cells, ${ }^{31}$ fibroblasts, ${ }^{32}$ and macrophages. ${ }^{17}$ It is therefore highly likely that the effects of zoledronate that we have identified here in rat VSMCs, apply more widely and could have a major impact on tissue remodeling and inflammatory activation caused by zoledronate. Further studies will be needed to address this interesting possibility.

In conclusion, our results conclusively demonstrate that zoledronate can increase expression of some MMPs in rat VSMCs. Furthermore, this is associated with stimulation of ROS production and consequent activation of the NF- $\kappa B$ pathway.

\section{Acknowledgments}

The authors would like to thank Dr Goksel Gokce, Ege University Faculty of Pharmacy and Dr Steve White, University of Bristol for valuable help and expertise on oxidative stress measurements. MZA would also like to thank Prof Levent Ustunes for kind help and encouragement. This study was supported by the British Heart Foundation grant CH95/001.

\section{Disclosure}

The authors have no conflicts of interest to disclose.

\section{References}

1. Ylitalo R, Syvala H, Tuohimaa P, Ylitalo P. Suppression of immunoreactive macrophages in atheromatous lesions of rabbits by clodronate. Pharmacol Toxicol. 2002;90(3):139-143.

2. Ylitalo-Heikkala R. Bisphosphonates and atherosclerosis: why? Lupus. 2006;15(12):903

3. Bevilacqua M, Dominguez LJ, Rosini S, Barbagallo M. Bisphosphonates and atherosclerosis: why? Lupus. 2005;14(9):773-779. 
4. Newby AC, Zaltsman AB. Molecular mechanisms in intimal hyperplasia. J Pathol. 2000;190(3):300-309.

5. Wu L, Zhu L, Shi WH, Zhang J, Ma D, Yu B. Zoledronate inhibits the proliferation, adhesion and migration of vascular smooth muscle cells. Eur J Pharmacol. 2009;602(1):124-131.

6. Albadawi H, Haurani MJ, Oklu R, et al. Differential effect of zoledronic acid on human vascular smooth muscle cells. J Surg Res. 2013;182(2):339-346.

7. Celiloglu M, Aydin Y, Balci P, Kolamaz T. The effect of alendronate sodium on carotid artery intima-media thickness and lipid profile in women with postmenopausal osteoporosis. Menopause. 2009;16(4):689-693.

8. Guzeloglu M, Gul M, Reel B, Yurekli I, Aykut K, Hazan E. The effects of zoledronic acid on neointimal hyperplasia: a rabbit carotid anastomosis model. Anadolu Kardiyol Derg. 2011;11(2):93-100.

9. Santos LL, Cavalcanti TB, Bandeira FA. Vascular effects of bisphosphonates-a systematic review. Clin Med Insights Endocrinol Diabetes. 2012;5:47-54.

10. Libby P. Mechanisms of acute coronary syndromes and their implications for therapy. N Engl J Med. 2013;368(21):2004-2013.

11. Newby AC. Matrix metalloproteinases regulate migration, proliferation, and death of vascular smooth muscle cells by degrading matrix and non-matrix substrates. Cardiovasc Res. 2006;69(3):614-624.

12. Green JR. Bisphosphonates: preclinical review. Oncologist. 2004;9 Suppl 4:3-13.

13. Melani C, Sangaletti S, Barazzetta FM, Werb Z, Colombo MP. Amino-biphosphonate-mediated MMP-9 inhibition breaks the tumorbone marrow axis responsible for myeloid-derived suppressor cell expansion and macrophage infiltration in tumor stroma. Cancer Res. 2007;67(23):11438-11446.

14. Green JR, Guenther A. The backbone of progress - preclinical studies and innovations with zoledronic acid. Crit Rev Oncol Hematol. 2011; 77 Suppl 1:S3-S12.

15. Hewer RC, Sala-Newby GB, Wu YJ, Newby AC, Bond M. PKA and Epac synergistically inhibit smooth muscle cell proliferation. $J \mathrm{Mol}$ Cell Cardiol. 2011;50(1):87-98.

16. Bond M, Chase AJ, Baker AH, Newby AC. Inhibition of transcription factor NF-kappaB reduces matrix metalloproteinase-1, -3 and -9 production by vascular smooth muscle cells. Cardiovasc Res. 2001; 50(3):556-565.

17. Reel B, Sala-Newby GB, Huang WC, Newby AC. Diverse patterns of cyclooxygenase-independent metalloproteinase gene regulation in human monocytes. Br J Pharmacol. 2011;163(8):1679-1690.

18. Tsaousi A, Williams $\mathrm{H}$, Lyon CA, et al. Wnt $4 / \beta$-catenin signaling induces VSMC Proliferation and is associated with intimal thickening. Circ Res. 2011;108(4):427-436.

19. Gokce G, Arun MZ. Ergothioneine produces relaxation in isolated rat aorta by inactivating superoxide anion. Eur Rev Med Pharmacol Sci. 2014;18(21):3339-3345.
20. Kishore N, Sommers C, Mathialagan S, et al. A selective IKK-2 inhibitor blocks NF-kappa B-dependent gene expression in interleukin-1 beta-stimulated synovial fibroblasts. J Biol Chem. 2003;278(35): 32861-32871.

21. Baldwin AS Jr. The NF-kappa B and I kappa B proteins: new discoveries and insights. Annu Rev Immunol. 1996;14:649-683.

22. Rajagopalan S, Meng XP, Ramasamy S, Harrison DG, Galis ZS. Reactive oxygen species produced by macrophage-derived foam cells regulate the activity of vascular matrix metalloproteinases in vitro. Implications for atherosclerotic plaque stability. J Clin Invest. 1996;98(11):2572-2579.

23. Amanso AM, Griendling KK. Differential roles of NADPH oxidases in vascular physiology and pathophysiology. Front Biosci (Schol Ed). 2012;4:1044-1064.

24. Basi DL, Hughes PJ, Thumbigere-Math V, etal. Matrix metalloproteinase-9 expression in alveolar extraction sockets of Zoledronic acid-treated rats. J Oral Maxillofac Surg. 2011;69(11):2698-2707.

25. Valleala H, Hanemaaijer R, Mandelin J, et al. Regulation of MMP-9 (gelatinase B) in activated human monocyte/macrophages by two different types of bisphosphonates. Life Sci. 2003;73(19):2413-2420.

26. Varghese $\mathrm{S}$, Canalis E. Alendronate stimulates collagenase 3 expression in osteoblasts by posttranscriptional mechanisms. $J$ Bone Miner Res. 2000;15(12):2345-2351.

27. Bain J, Plater L, Elliott M, et al. The selectivity of protein kinase inhibitors: a further update. Biochem J. 2007;408(3):297-315.

28. Mengshol JA, Vincenti MP, Coon CI, Barchowsky A, Brinckerhoff CE. Interleukin-1 induction of collagenase 3 (matrix metalloproteinase 13) gene expression in chondrocytes requires $\mathrm{p} 38$, c-Jun N-terminal kinase, and nuclear factor kappaB: differential regulation of collagenase 1 and collagenase 3. Arthritis Rheum. 2000;43(4):801-811.

29. Nagano Y, Matsui H, Shimokawa O, et al. Bisphosphonate-induced gastrointestinal mucosal injury is mediated by mitochondrial superoxide production and lipid peroxidation. J Clin Biochem Nutr. 2012;51(3): 196-203.

30. Karabulut AB, Gul M, Karabulut E, Kiran TR, Ocak SG, Otlu O. Oxidant and antioxidant activity in rabbit livers treated with zoledronic acid. Transplant Proc. 2010;42(9):3820-3822.

31. Cheng CY, Hsieh HL, Hsiao LD, Yang CM. PI3-K/Akt/JNK/NF- - is essential for MMP-9 expression and outgrowth in human limbal epithelial cells on intact amniotic membrane. Stem Cell Res. 2012;9(1): 9-23.

32. Bond M, Fabunmi RP, Baker AH, Newby AC. Synergistic upregulation of metalloproteinase- 9 by growth factors and inflammatory cytokines: an absolute requirement for transcription factor NF-kappa B. FEBS Lett. 1998;435(1):29-34.
Drug Design, Development and Therapy

\section{Publish your work in this journal}

Drug Design, Development and Therapy is an international, peerreviewed open-access journal that spans the spectrum of drug design and development through to clinical applications. Clinical outcomes, patient safety, and programs for the development and effective, safe, and sustained use of medicines are a feature of the journal, which

\section{Dovepress}

has also been accepted for indexing on PubMed Central. The manuscript management system is completely online and includes a very quick and fair peer-review system, which is all easy to use. Visit http://www.dovepress.com/testimonials.php to read real quotes from published authors. 